\title{
Efektivitas Metode Pembelajaran terhadap Pengetahuan Keamanan Pangan Siswa Sekolah Tingkat Menengah
}

\author{
Effect of Learning Method Towards Food Safety Knowledge \\ of High School Students
}

\author{
Yanti Ratnasari ${ }^{1)}$, Rahmawati ${ }^{2}$, Winiati P. Rahayu ${ }^{2,3)^{*}}$ \\ ${ }^{1)}$ Badan Pengawas Obat dan Makanan Republik Indonesia \\ ${ }^{2)}$ Departemen Ilmu dan Teknologi Pangan, Fakultas Teknologi Pertanian, Institut Pertanian Bogor, Bogor \\ ${ }^{3)}$ Southeast Asian Food and Agricultural Science and Technology Center, LPPM, Institut Pertanian Bogor, Bogor
}

\begin{abstract}
Food safety education program needs to be given to the high school community, especially for junior and senior high school students who are entering adolescence. Appropriate learning methods required in the delivery of food safety information. The aim of this study was determining the effect of the way food safety intervention with active and passive learning method to the food safety knowledge of high school students. Analysis of different test with independent t-test on both active and passive learning methods of intervention showed there was no different between both methods. The result of the effect of food safety intervention with active and passive learning methods by paired sample t-test showed increasing the average score of food knowledge $(p \leq 0.05)$ between before and after the intervention of 2.18 and 2.54 $\%$. Based on the distribution of score of knowledge, active learning method just increased significantly only for senior high school students in science program. Correlation analysis showed the higher school level did not ensure higher food safety knowledge as well.
\end{abstract}

Keywords: adolescents, food safety, knowledge, learning method

\begin{abstract}
Abstrak. Program edukasi keamanan pangan perlu diberikan pada komunitas sekolah tingkat menengah terutama pada siswa yang sedang memasuki masa remaja. Metode pembelajaran yang tepat diperlukan dalam penyampaian materi keamanan pangan. Penelitian ini bertujuan untuk menguji pengaruh metode intervensi keamanan pangan dengan metode pembelajaran aktif dan pasif terhadap pengetahuan keamanan pangan siswa SMP dan SMA. Hasil uji beda independent $t$-test antara metode intervensi pembelajaran aktif dan pasif menunjukkan bahwa tidak ada perbedaan pada kedua metode intervensi yang digunakan. Analisis pengaruh intervensi pembelajaran aktif dan pasif dengan paired sample t-test memberikan peningkatan skor rata-rata pengetahuan pangan yang signifikan $(\mathrm{p} \leq 0.05)$ antara sebelum dan sesudah intervensi masingmasing sebesar $2.18 \%$ untuk kelompok aktif dan $2.54 \%$ untuk kelompok pasif. Metode pembelajaran aktif hanya berhasil meningkatkan pengetahuan keamanan pangan yang signifikan pada tingkat SMA jurusan IPA. Analisis korelasi menunjukkan semakin tinggi tingkat sekolah tidak menjamin bahwa pengetahuan mengenai keamanan pangan siswa lebih baik.
\end{abstract}

Kata Kunci: keamanan pangan, metode pembelajaran, pengetahuan, remaja

Aplikasi Praktis: Hasil penelitian ini dapat menjadi acuan dalam menyusun program edukasi keamanan pangan sekolah tingkat menengah khususnya untuk menentukan metode pembelajaran yang tepat. Pembelajaran materi keamanan pangan yang tepat akan meningkatkan pengetahuan siswa sehingga diharapkan siswa akan memiliki sikap dan perilaku keamanan pangan yang baik.

\section{PENDAHULUAN}

Aksi Nasional Gerakan menuju Pangan Jajanan Anak Sekolah yang Aman, Bermutu, dan Bergizi (AN-PJAS) merupakan upaya yang dilakukan pemerintah melalui Badan POM untuk meningkatkan kesadaran masyarakat terhadap PJAS yang aman, bermutu dan bergizi sejak tahun 2011. Laporan Badan POM RI mengenai keracunan pangan menunjukkan bahwa lokasi kejadian luar biasa (KLB) keracunan pangan paling tinggi terjadi di Sekolah Dasar (19.15\%), Sekolah Menengah Pertama
(6.38 \%), dan tidak terjadi di Sekolah Lanjutan Tingkat Atas (BPOM 2014). Menyikapi hal tersebut AN-PJAS dilakukan utamanya di Sekolah Dasar, namun komunitas sekolah menengah juga perlu mendapatkan perhatian sebagai target sasaran dari program keamanan pangan nasional. Siswa sekolah tingkat menengah merupakan remaja yang sedang berada pada tahap menuju masa dewasa sehingga mulai dapat membuat keputusan sendiri dalam penentuan dan pemilihan pangan yang mereka konsumsi. 
Makanan yang dipilih remaja merupakan refleksi dari berbagai faktor, meliputi kebiasaan makan keluarga, kelompok teman sebaya (peer group), dan pengaruh iklan media. Teman sebaya mempunyai pengaruh yang sangat besar pada masa remaja. Jaccard et al. (2005) menyebutkan bahwa munculnya hubungan sebaya yang kuat merupakan salah satu kunci perubahan perkembangan awal remaja. Selain itu, teman sebaya dapat memiliki dampak positif ataupun negatif pada perilaku kesehatan remaja. Keinginan untuk diterima oleh teman sebaya menyebabkan pemilihan jenis makanan dan sikap keamanan pangan banyak dipengaruhi pilihan teman sebaya. Hal tersebut menjadikan hubungan teman sebaya masih memiliki peran yang kuat terhadap keputusan remaja.

Berdasarkan alasan tersebut, pemberian materi keamanan pangan perlu dilaksanakan melalui metode penyampaian yang dapat dipahami siswa sekolah tingkat menengah sebagai upaya untuk meningkatkan pengetahuan keamanan pangan. Menurut Kim et al. (2012), pendidikan kesehatan untuk remaja yang disampaikan oleh teman sebaya memberikan dampak positif karena teman sebaya lebih memahami keadaan dan lingkungan sesamanya. Pemilihan metode intervensi keamanan pangan pembelajaran aktif dan pasif didasarkan pada hubungan teman sebaya yang memiliki banyak kesamaan. Metode pembelajaran aktif melibatkan kegiatan diskusi kelompok antar siswa, sedangkan metode pembelajaran pasif merupakan metode pembelajaran satu arah dari pemateri. Penelitian ini bertujuan untuk mengukur pengaruh intervensi keamanan pangan terhadap pengetahuan siswa sekolah menengah, membedakan pengaruh pemberian penyuluhan dengan metode aktif dan pasif, serta menentukan korelasi antara tingkat sekolah siswa yang berada pada tingkat pendidikan menengah yaitu Sekolah Menengah Pertama (SMP) dan Sekolah Menengah Atas (SMA) terhadap pengetahuan keamanan pangannya.

\section{BAHAN DAN METODE}

\section{Bahan}

Bahan yang digunakan meliputi materi pembelajaran keamanan pangan yang dikembangkan Badan POM yang meliputi isu keamanan pangan, menjaga kebersihan, pengenalan keamanan pangan, membaca label pangan, bahaya pada pangan dan penyimpanan dan penyajian pangan yang baik. Selain itu digunakan kuesioner pretest dan posttest pembelajaran keamanan pangan.

\section{Penentuan sampel responden}

Sampel responden siswa sekolah tingkat menengah ditentukan dengan metode purposive sampling. Responden pada penelitian ini terdiri dari siswa sekolah tingkat menengah, baik tingkat SMP (2 sekolah) maupun SMA (2 sekolah) masing-masing dari daerah Depok, Jakarta, dan Serang. Sekolah-sekolah tersebut dipilih berdasarkan kriteria inklusi atau kriteria subjek penelitian yang perlu dipenuhi oleh setiap anggota populasi yang dapat diambil sebagai sampel yang ditetapkan antara lain (1) sekolah tingkat menengah negeri yang memiliki fasilitas multimedia seperti proyektor dan jaringan internet, (2) siswa kelas dua SMP dan kelas dua SMA (program IPA dan IPS). Siswa sekolah yang mengikuti dua kegiatan ini terdiri dari 30 siswa dari setiap kelompok intervensi (30 siswa SMP, 30 siswa SMA-IPA, 30 siswa SMA-IPS).

\section{Penyusunan kuesioner}

Penyusunan kuesioner pertanyaan pretest dan posttest mengacu pada Panduan Aktivitas Keamanan Pangan Berbasis Masyarakat (Community-Based) di Komunitas Sekolah Tingkat Menengah dari BPOM (2015b). Pertanyaan dalam kuesioner disusun berdasarkan materi keamanan pangan yang digunakan pada intervensi untuk mengetahui aspek pengetahuan keamanan pangan siswa. Pertanyaan dalam penyusunan kuesioner mencakup isu keamanan pangan, menjaga kebersihan, pengenalan keamanan pangan, membaca label pangan, bahaya pada pangan dan penyimpanan dan penyajian pangan yang baik. Selanjutnya, kuesioner yang telah disusun diujicobakan kepada 40 responden siswa SMA. Analisis pengujian kuesioner dilakukan dengan menggunakan program SPSS. Hasil analisis uji coba kuesioner digunakan untuk perbaikan isi kuesioner.

\section{Pelaksanaan intervensi}

Responden diberikan pretest terlebih dahulu sebelum diberikan intervensi. Pemberian intervensi keamanan pangan dilakukan pada dua kelompok yaitu kelompok pembelajaran aktif (30 siswa) dan kelompok pembelajaran pasif (30 siswa). Jenis intervensi keamanan pangan yang digunakan dapat dilihat pada Tabel 1 .

\begin{tabular}{|c|c|}
\hline Metode Pembelajaran Aktif & Metode Pembelajaran Pasif \\
\hline $\begin{array}{l}\text { Siswa mencari informasi } \\
\text { yang berkaitan dengan } \\
\text { topik melalui internet atau } \\
\text { media cetak } \\
\text { - Siswa berdiskusi dalam } \\
\text { kelompoknya sesuai topik } \\
\text { - } \\
\text { Setiap kelompok } \\
\text { mempresentasikan hasil } \\
\text { diskusi } \\
\text { - Kelompok lain memberikan } \\
\text { komentar, saran, } \\
\text { pertanyaan) kepada } \\
\text { kelompok yang presentasi }\end{array}$ & $\begin{array}{ll}\text { - } & \text { Fasilitator } \\
\text { mempresentasikan dan } \\
\text { menjelaskan materi } \\
\text { keamanan pangan } \\
\text { - } & \text { Siswa mendengarkan } \\
\text { penjelasan fasilitator } \\
\text { - } & \text { Sesi tanya jawab dilakukan } \\
& \text { dengan waktu yang singkat }\end{array}$ \\
\hline
\end{tabular}

Intervensi dilakukan oleh Fasilitator Keamanan Pangan Sekolah (FKPS) yang telah diseleksi oleh Badan POM. Intervensi dilakukan selama 6 minggu. Intervensi setiap pertemuan dilakukan selama 90 menit dengan selang waktu untuk masing-masing topik selama 1 minggu. Materi intervensi meliputi topik isu keamanan pangan, menjaga kebersihan, pengenalan keamanan pangan, membaca label pangan, bahaya pada pangan dan penyimpanan dan penyajian pangan yang baik. Setelah intervensi dilakukan posttest dengan menggunakan kuesioner yang sama dengan pretest. 


\section{Evaluasi intervensi}

Data pretest dan posttest siswa yang diperoleh setelah intervensi diproses dengan tahapan entry, editing, coding, scoring, dan analisis dengan menggunakan program Microsoft Excel dan SPSS 22.0 for windows. Skor pengetahuan siswa dihitung dalam persentase dengan rumus sebagai berikut :

$$
\text { Skor }=\frac{\text { skor yang diperoleh }}{\text { skor maksimum }} \times 100
$$

Setelah scoring dilakukan, analisis uji beda dilakukan dengan independent t-test menggunakan program SPSS 22.0 pada data perubahan skor rata-rata pengetahuan untuk melihat perbedaan pengetahuan antara kelompok aktif dan kelompok pasif setelah intervensi. Analisis uji beda kenaikan skor rata-rata pada tiga kota juga dilakukan untuk melihat perbedaan pengetahuan keamanan pangan siswa pada tiga daerah tersebut. Selanjutnya, analisis hasil pengukuran perbedaan pengetahuan keamanan pangan siswa sebelum dan sesudah intervensi pada kedua kelompok dilakukan dengan menggunakan paired sample t-test dari program SPSS 22.0. Analisis ini menggunakan hasil data scoring hasil prestest dan posttest siswa. Uji korelasi Spearman dilakukan untuk mengetahui hubungan variabel yaitu tingkat sekolah dan pengetahuan keamanan pangan siswa (Yasmin dan Madanijah 2010).

\section{HASIL DAN PEMBAHASAN}

\section{Karakteristik responden}

Karakteristik responden difokuskan pada tingkat sekolah yaitu SMP dan SMA di tiga kota (Depok, Jakarta, Serang). Gambaran distribusi karakteristik responden berdasarkan data Program Keamanan Pangan Sekolah (PKPS) dapat dilihat pada Tabel 2.

Tabel 2. Data responden ${ }^{\mathrm{a}}$

\begin{tabular}{|c|c|c|c|c|c|c|}
\hline \multirow{2}{*}{$\begin{array}{c}\text { Jenis } \\
\text { Responden }\end{array}$} & \multicolumn{2}{|c|}{ Kelas Aktif } & \multicolumn{2}{|c|}{ Kelas Pasif } & \multicolumn{2}{|c|}{ Total } \\
\hline & $\mathrm{n}^{\mathrm{b}}$ & $\%^{\mathrm{b}}$ & $\mathbf{n}$ & $\%$ & $\mathbf{N}$ & $\%$ \\
\hline \multicolumn{7}{|l|}{ Daerah Depok } \\
\hline SMP & 60 & 18.40 & 63 & 17.60 & 123 & 17.98 \\
\hline SMA & 52 & 15.95 & 59 & 16.48 & 111 & 16.23 \\
\hline \multicolumn{7}{|l|}{ Daerah } \\
\hline \multicolumn{7}{|l|}{ Jakarta } \\
\hline SMP & 54 & 16.56 & 57 & 15.92 & 111 & 16.23 \\
\hline SMA & 63 & 19.33 & 61 & 17.04 & 124 & 18.13 \\
\hline \multicolumn{7}{|c|}{ Daerah Serang } \\
\hline SMP & 61 & 18.71 & 61 & 17.04 & 122 & 17.84 \\
\hline SMA & 36 & 11.04 & 57 & 15.92 & 93 & 13.60 \\
\hline \multicolumn{7}{|c|}{ Tingkat sekolah } \\
\hline SMP & 175 & 53.68 & 181 & 50.56 & 356 & 52.05 \\
\hline SMA & 151 & 46.32 & 193 & 53.91 & 328 & 47.95 \\
\hline Total & 326 & 100.00 & 358 & 100.00 & 684 & 100.00 \\
\hline
\end{tabular}

Berdasarkan Wilcock et al. (2004), karakteristik demografi konsumen dalam lingkup keamanan pangan seperti gender, usia, tingkat pendidikan, dan status ekonomi memengaruhi sikap konsumen terhadap keamanan pangan. Sikap konsumen terhadap keamanan pangan tersebut berkaitan erat dengan pengetahuan keamanan pangannya. Lee et al. (2017) juga menyatakan bahwa tingkat pendidikan dapat memengaruhi pengetahuan keamanan pangan seseorang. Faktor tingkat sekolah dalam penelitian ini tidak dapat diabaikan. Hal tersebut didasarkan pada penelitian Almansour et al. (2016) mengenai pengetahuan kebersihan pangan yang menunjukkan hasil bahwa siswa sekolah tingkat menengah atas memiliki pengetahuan yang lebih tinggi dibandingkan siswa sekolah tingkat dasar dan siswa sekolah tingkat menengah pertama.

\section{Pengetahuan keamanan pangan siswa sekolah tingkat menengah}

Pengetahuan merupakan domain yang sangat penting untuk terbentuknya tindakan seseorang (overt behaviour) sebagai hasil yang diperoleh setelah melakukan penginderaan terhadap suatu objek tertentu (Notoatmodjo 2007). Aspek pengetahuan perlu diperhatikan dalam suatu program edukasi. Keberlanjutan dan pengawasannya dalam program edukasi juga diperlukan untuk mengubah pengetahuan yang diperoleh siswa menjadi sikap dan mengubah sikap menjadi perilaku (Sanlier dan Konaklioglu 2012). Tabel 3 menyajikan persentase jawaban benar hasil pretest siswa dari tiga kota.

Tabel 3. Hasil pretest siswa ${ }^{\mathrm{a}}$

\begin{tabular}{|c|c|c|c|c|}
\hline \multirow[t]{2}{*}{ Topik } & \multicolumn{3}{|c|}{$\begin{array}{c}\text { Persentase Jawaban Benar } \\
(\%)^{\text {b }}\end{array}$} & \multirow{2}{*}{$\begin{array}{c}\text { Rata-rata } \\
\text { pretest } \\
(\%)^{\mathrm{b}}\end{array}$} \\
\hline & Depok & Jakarta & Serang & \\
\hline $\begin{array}{l}\text { Isu keamanan } \\
\text { pangan }\end{array}$ & 88.78 & 85.43 & 84.19 & 86.13 \\
\hline $\begin{array}{l}\text { Menjaga } \\
\text { kebersihan }\end{array}$ & 86.89 & 89.36 & 75.81 & 84.02 \\
\hline $\begin{array}{l}\text { Pengenalan } \\
\text { keamanan } \\
\text { pangan }\end{array}$ & 84.19 & 78.87 & 78.29 & 80.45 \\
\hline $\begin{array}{l}\text { Membaca label } \\
\text { pangan }\end{array}$ & 79.77 & 77.02 & 74.26 & 77.02 \\
\hline $\begin{array}{l}\text { Bahaya pada } \\
\text { pangan }\end{array}$ & 75.32 & 72.23 & 72.44 & 73.33 \\
\hline $\begin{array}{l}\text { Penyimpanan dan } \\
\text { penyajian pangan } \\
\text { yang baik }\end{array}$ & 57.98 & 53.19 & 58.29 & 56.49 \\
\hline Rata-rata & 78.82 & 76.02 & 73.88 & 76.24 \\
\hline
\end{tabular}

Keterangan: a Sumber: BPOM (2016).; ${ }^{\text {b}} \%$ : persentase jawaban benar

Hasil pretest menunjukkan bahwa persentase tertinggi dari siswa menjawab benar atas topik isu keamanan pangan yaitu sebesar $86.13 \%$. Pada umumnya siswa telah mengetahui dan paham mengenai informasi dan isu keamanan pangan saat ini. Salah satu topik isu keamanan pangan adalah kasus keracunan pangan pada lembaga pendidikan yang menempati urutan kedua tertinggi yaitu sebesar $27.87 \%$ pada kasus keracunan pangan tahun 2015 (BPOM 2015a). Kelompok usia muda termasuk siswa memiliki risiko tinggi untuk penyakit bawaan pangan (Mullan et al. 2015). Selain itu, topik isu keamanan pangan yang banyak mendapat perhatian adalah penyalahgunaan bahan berbahaya yang sebagian besar disalahgunakan pada pangan jajanan anak sekolah (PJAS).

Selanjutnya topik menjaga kebersihan memiliki persentase jawaban benar sebesar $84.02 \%$. Hasil ini menunjukkan bahwa sebagian besar siswa telah memiliki 
dasar pengetahuan kebersihan yang baik seperti cara cuci tangan yang baik dan benar, cara menjaga kebersihan peralatan makan serta kebersihan lingkungan kantin sekolah. Menjaga kebersihan termasuk salah satu pilar untuk keamanan pangan. Undang-Undang Pangan (No. 18 Tahun 2012) menyatakan bahwa keamanan pangan adalah kondisi dan upaya yang diperlukan untuk mencegah Pangan dari kemungkinan cemaran biologis, kimia, dan benda lain yang dapat mengganggu, merugikan, dan membahayakan kesehatan manusia serta tidak bertentangan dengan agama, keyakinan, dan budaya masyarakat sehingga aman untuk dikonsumsi.

Pembacaan label pangan juga telah dimengerti oleh siswa (77.02\%). Chung et al. (2010) menyatakan bahwa perlu diadakannya program edukasi yang fokus pada peningkatan kesadaran dan penggunaan label pangan pada remaja karena terdapat hubungan positif yang signifikan antara kesadaran dan pemahaman label pangan pada kebiasaan makan seseorang. Seseorang yang terbiasa membaca label pangan memiliki indeks massa tubuh, perilaku diet, dan pemahaman informasi nilai gizi yang lebih baik. Hasil penelitian Septian dan Rahayu (2015) juga menunjukkan tingkat pengetahuan Industri Rumah Tangga Pangan (IRTP) di Kota Bogor terhadap peraturan label pangan masih kurang (hanya 16\% IRTP yang benar-benar paham).

Topik mengenai penyimpanan dan penyajian pangan memiliki persentase jawaban benar yang paling rendah (56.49\%). Penelitian Naina et al. (2016) juga menunjukkan bahwa hanya terdapat sedikit siswa (22.55 dan $10.78 \%$ ) yang menjawab benar pada pernyataan mengenai cara menyimpan pangan pada suhu yang aman sehingga siswa SMA masih perlu diberi penyuluhan agar mengetahui cara menyimpan pangan pada suhu yang aman. Oleh karena itu siswa perlu diberikan materi yang lebih mendalam mengenai topik tersebut.

\section{Pengaruh intervensi terhadap pengetahuan keama- nan pangan siswa sekolah tingkat menengah}

Hasil posttest pengetahuan keamanan pangan siswa setelah intervensi dilakukan dapat dilihat pada Tabel 4. Secara umum terjadi peningkatan persentase jawaban benar pada seluruh topik kecuali pada topik isu keamanan pangan dan membaca label pangan yang justru terjadi penurunan sebesar 0.68 dan $0.02 \%$. Penurunan tersebut dapat terjadi karena kemungkinan tidak ada isu keamanan pangan baru yang didiskusikan. Sedangkan topik membaca label kemungkinan belum diajarkan secara jelas kepada siswa. Topik membaca label sebaiknya diberikan dengan praktik langsung membaca label pangan sehingga siswa lebih mengerti.

Kenaikan rata-rata persentase pada daerah Depok, Jakarta, dan Serang tidak terlalu tinggi yaitu masingmasing 3.03, 2.17, dan 2.09\%. Hasil tersebut tidak berbeda nyata dengan nilai $p$-value $\geq 0.05$. Berdasarkan hasil tersebut, materi keamanan pangan yang digunakan untuk intervensi perlu dilakukan perbaikan konten materi dan penyampaian yang lebih baik oleh para fasilitator.

\section{Pengaruh metode pembelajaran pada pengetahuan keamanan pangan siswa sekolah tingkat menengah}

Hasil analisis uji beda antara metode pembelajaran aktif dan pasif dengan metode independent sample t-test menunjukkan terjadi kenaikkan skor pengetahuan siswa pada pembelajaran aktif sebesar $2.18 \%$ dan pada pembelajaran pasif sebesar $2.54 \%$ (Tabel 5). Hasil analisis perbedaan antara metode pembelajaran aktif dan pasif tidak berbeda nyata dengan nilai signifikansi sebesar 0.735 ( $\mathrm{P} \geq 0.05)$. Metode pembelajaran aktif belum efektif untuk meningkatkan pengetahuan keamanan pangan siswa dibandingkan dengan metode pembelajaran pasif.

Hasil ini berbeda dengan hasil penelitian Wang et al. (2015) yang menunjukkan bahwa metode edukasi yang melibatkan aktivitas teman sebaya seperti diskusi dan presentasi kelompok lebih efektif dalam mengembangkan pengetahuan remaja dibandingkan dengan kelompok kontrol yang tidak diberikan aktivitas tersebut. Metode pembelajaran pada edukasi keamanan pangan untuk siswa sekolah menengah lebih cenderung melibatkan interaksi teman sebaya (peer teaching) (Bryd-Bredbenner et al. 2010). Perbedaan hasil ini dapat disebabkan oleh intervensi metode pembelajaran aktif yang belum terlaksana secara efisien. Pada pelaksanaannya masih terdapat siswa yang masih mengandalkan teman lain untuk mencari bahan-bahan diskusi yang terbukti dari bantuan fasilitator dalam diskusi.

Tabel 4. Hasil posttest siswa ${ }^{a}$

\begin{tabular}{|c|c|c|c|c|c|c|c|c|}
\hline \multirow{3}{*}{ Topik } & \multicolumn{6}{|c|}{ Persentase Jawaban Benar (\%) } & \multicolumn{2}{|c|}{ Rata-rata (\%) } \\
\hline & \multicolumn{2}{|c|}{ Depok } & \multicolumn{2}{|c|}{ Jakarta } & \multicolumn{2}{|c|}{ Serang } & \multirow{2}{*}{ Posttest } & \multirow{2}{*}{$\Delta^{\mathrm{c}}$} \\
\hline & Posttest & $\Delta^{\mathrm{c}}$ & Posttest & $\Delta^{\mathrm{c}}$ & Posttest & $\Delta^{\mathrm{c}}$ & & \\
\hline Isu keamanan pangan & 87.07 & -1.71 & 83.83 & -1.60 & 85.93 & 1.74 & 85.61 & -0.52 \\
\hline Menjaga kebersihan & 88.03 & 1.14 & 88.94 & -0.42 & 76.43 & 0.62 & 84.47 & 0.45 \\
\hline $\begin{array}{l}\text { Pengenalan keamanan } \\
\text { pangan }\end{array}$ & 85.47 & 1.28 & 83.26 & 4.39 & 84.65 & 6.36 & 84.46 & 4.01 \\
\hline Membaca label pangan & 80.91 & 1.14 & 76.60 & -0.42 & 73.49 & -0.77 & 77.00 & -0.02 \\
\hline Bahaya pada pangan & 80.98 & 5.66 & 75.64 & 3.41 & 74.88 & 2.44 & 77.17 & 3.84 \\
\hline $\begin{array}{l}\text { Penyimpanan dan } \\
\text { penyajian pangan yang } \\
\text { baik }\end{array}$ & 68.66 & 10.68 & 60.85 & 7.66 & 60.47 & 2.18 & 63.33 & 6.84 \\
\hline Rata-rata & 81.86 & 3.03 & 78.19 & 2.17 & 75.98 & 2.09 & 78.67 & 2.43 \\
\hline
\end{tabular}


Tabel 5. Pengetahuan keamanan pangan siswa ${ }^{\mathrm{a}}$

\begin{tabular}{|c|c|c|c|c|}
\hline \multirow{2}{*}{ Kelompok } & \multicolumn{2}{|c|}{ Rata-rata skor (\%) } & \multirow{2}{*}{ Perubahan (\%) } & \multirow{2}{*}{$P$-value ${ }^{b}$} \\
\hline & Sebelum & Sesudah & & \\
\hline Kelompok aktif & $76.78 \pm 11.99$ & $78.96 \pm 11.67$ & 2.18 & $0.005^{c}$ \\
\hline Kelompok pasif & $76.56 \pm 11.85$ & $79.11 \pm 11.84$ & 2.54 & $0.001^{\mathrm{c}}$ \\
\hline \multicolumn{5}{|l|}{ Kelompok aktif } \\
\hline Tingkat SMP & $77.37 \pm 11.67$ & $78.57 \pm 12.03$ & 1.20 & 0.240 \\
\hline Tingkat SMA-IPA & $75.59 \pm 12.54$ & $79.06 \pm 11.03$ & 3.47 & $0.026^{c}$ \\
\hline Tingkat SMA-IPS & $76.74 \pm 12.17$ & $79.85 \pm 11.63$ & 3.11 & 0.093 \\
\hline \multicolumn{5}{|l|}{ Kelompok pasif } \\
\hline Tingkat SMP & $75.77 \pm 10.84$ & $78.40 \pm 11.00$ & 2.62 & $0.007^{c}$ \\
\hline Tingkat SMA-IPA & $82.16 \pm 10.77$ & $85.30 \pm 11.80$ & 3.13 & $0.035^{c}$ \\
\hline Tingkat SMA-IPS & $74.45 \pm 13.09$ & $76.50 \pm 12.03$ & 2.04 & 0.213 \\
\hline
\end{tabular}

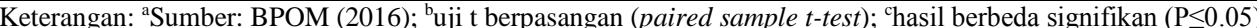

Metode pembelajaran aktif hanya efektif pada siswa SMA jurusan IPA $(\mathrm{P} \leq 0.05)$. Sementara untuk kelompok dengan intervensi metode pembelajaran pasif memberikan hasil peningkatan skor yang signifikan $(\mathrm{P} \leq 0.05)$ pada tingkat SMP dan SMA jurusan IPA. Intervensi keamanan pangan tidak memberikan hasil yang signifikan $(\mathrm{P} \geq 0.05)$ pada siswa tingkat SMA jurusan IPS. Pada jurusan IPA terjadi peningkatan pengetahuan keamanan pangan yang signifikan karena mereka telah memiliki dasar pengetahuan keamanan pangan melalui mata pelajaran pengetahuan alam khususnya biologi dan kimia. Pada siswa SMP tidak terjadi kenaikan pengetahuan yang signifikan karena mereka masih dalam tahap awal pembelajaran ilmu pengetahuan alam. Siswa SMA jurusan IPA lebih mudah mencari dan memahami informasi keamanan pangan yang diperoleh pada metode pembelajaran aktif. Pembelajaran aktif dan pasif belum dapat menghasilkan peningkatan skor pengetahuan keamanan pangan siswa SMA jurusan IPS sehingga perlu dilakukan pengembangan atau kombinasi metode pembelajaran agar lebih meningkatkan skor pengetahuan siswa.

\section{Korelasi antara tingkat sekolah terhadap pengeta- huan keamanan pangan siswa}

Hasil analisis korelasi Spearman menunjukkan nilai signifikansi korelasi yang lebih besar dari $0.05(\mathrm{p}=0.094)$ dengan nilai koefisien korelasi 0.064 yang menunjukkan tidak ada korelasi antara tingkat sekolah dengan pengetahuan keamanan pangan siswa. Berdasarkan hasil tersebut, dapat disimpulkan bahwa semakin tinggi tingkat sekolah tidak menjamin pengetahuan mengenai keamanan pangan siswa yang lebih tinggi. Materi keamanan pangan yang diberikan saat intervensi dapat dimengerti oleh seluruh siswa dengan kemampuan pemahaman yang sama antar siswa tingkat sekolah.

Hasil tersebut tidak sesuai dengan pernyataan Norazmir et al. (2012) yang menyatakan bahwa tingkat pendidikan atau sekolah memengaruhi pengetahuan keamanan pangan. Ketidaksesuaian hasil dengan literatur tersebut disebabkan sebagian siswa pernah memperoleh informasi keamanan pangan di luar lingkungan sekolah seperti keluarga atau media informasi cetak maupun digital. Sekolah perlu memberikan perhatian lebih pada edukasi keamanan pangan untuk siswa dalam rangka membentuk agen perubahan untuk membantu pelaksanaan program keamanan pangan sekolah dengan baik.

\section{KESIMPULAN}

Hasil penelitian pada siswa sekolah tingkat menengah di daerah Depok, Jakarta, dan Serang menunjukkan bahwa pembelajaran aktif dan pasif memberikan hasil peningkatan skor pengetahuan siswa yang sama sehingga metode pembelajaran aktif belum efektif dalam meningkatkan pengetahuan keamanan pangan siswa. Pembelajaran aktif hanya memberikan hasil beda signifikan $(\mathrm{p} \leq 0.05)$ pada tingkat SMA jurusan IPA saja. Pada siswa SMP dan SMA jurusan IPS perlu dilakukan pembelajaran keamanan pangan yang lebih atraktif agar dapat meningkatkan pengetahuan siswa. Hasil analisis korelasi menunjukkan tidak terdapat hubungan antara tingkat sekolah dengan pengetahuan keamanan pangan siswa sehingga semakin tinggi tingkat sekolah tidak menjamin bahwa pengetahuan mengenai keamanan pangan siswa lebih baik.

\section{DAFTAR PUSTAKA}

Almansour M, Sami W, Al-Rashedy OS, Alsaab RS, Alfayez AS, Almarri NR. 2016. Knowledge, attitude, and practice (KAP) of food hygiene among schools students in Majmaah city, Saudi Arabia. J Pakistan Medical Assoc 66(4): 442-446. DOI: $10.7707 / \mathrm{hmj}$. 598.

[BPOM] Badan Pengawas Obat dan Makanan. 2014. Laporan Tahunan 2014 Badan Pengawas Obat dan Makanan. Jakarta (ID): BPOM RI.

[BPOM] Badan Pengawas Obat dan Makanan. 2015a. Laporan Tahunan 2015 Badan Pengawas Obat dan Makanan. Jakarta (ID): BPOM RI.

[BPOM] Badan Pengawas Obat dan Makanan. 2015b. Panduan Aktivitas Keamanan Pangan Berbasis Masyarakat (Community-Based) di Komunitas Sekolah Tingkat Menengah. Jakarta (ID): SPKPBPOM RI.

[BPOM] Badan Pengawas Obat dan Makanan. 2016. Program Keamanan Pangan Sekolah. Jakarta (ID): BPOM RI.

Chung EJ, Jeon JS, Ahn HS. 2010. Reading and understanding of food \& nutrition labels and dietary behaviours of female middle and high school students. J Korean Dietetic Accoc 16(3): 239-254. 
Jaccard J, Blanton H, Dodge T. 2005. Peer influences on risk behavior: an analysis of the eff ects of a close friend. J Developmental Psychology 41(1): 135-147. DOI: $10.1037 / 0012-1649.41 .1 .135$.

Kim EJ, Pai AJ, Kang NE, Kim WK, Kim YS, Moon HK, Ha AW. 2012. The effects of food safety education on adolescents' hand hygiene behavior: an analysis of stages of change. Nutr Res Practice 6(2): 169-174. DOI: 10.4162/nrp.2012.6.2.169

Lee HK, Halim HA, Thong KL, Chai LC. 2017. Assessment of food safety knowledge, attitude, selfreported practices, and microbiological hand hygiene of food handlers. Int $\mathrm{J}$ Environ Res Public Health 14(1): 1-14. DOI: 10.3390/ijerph14010055

Mullan BA, Wong C, Todd J, Davis E, Kothe EJ. 2015. Food safety knowledge in adolescents and young adults. British Food J 117(1): 50-61. DOI: 10.1108/BFJ-03-2013-0060.

Naina HSBA, Kuswardinah I, Dewi S. 2016. Knowledge, attitude, and practice on food safety among senior high school students in Jatinangor from August November 2013. Althea Medical J 3(2): 206-211. DOI: $10.15850 /$ amj.v3n2.797.

Norazmir MN, Hasyimah MA Noor, Shafurah AS, Sabariah BS, Ajau D, Norazlansh H. 2012. Knowledge and practices on food safety among secondary school students in Johor Bahru, Johor, Malaysia. Pakistan J Nutr 11(2): 110-115. DOI: 10.3923/pjn.2012.110.115.
Notoatmodjo S. 2007. Kesehatan Masyarakat: Ilmu dan Seni. Jakarta (ID): Rineka Cipta. ISBN: 978-979518-890-2.

Pemerintah Republik Indonesia. 2012. Undang-Undang Republik Indonesia Nomor 18 Tahun 2012 tentang Pangan. Jakarta (ID): Sekretariat Negara.

Sanlier N, Konaklioglu E. 2012. Food safety knowledge, attitude, and food handling practices of students. British Food J 114(4): 469-480. DOI: 10.1108/000 70701211219504.

Septian J, Rahayu WP. 2015. Pengetahuan pelabelan produsen industri rumah tangga pangan di kota Bogor. J Mutu Pangan 1(2): 67-72.

Wilcock A, Maria P, Joseph K, May A. 2004. Consumer attitudes, knowledge, and behaviour: a review of food safety issuses. Trends Food Safety Technol 15: 56-66. DOI: 10.1016/j.tifs.2003.08.004.

Yasmin G, Madanijah S. 2010. Perilaku penjaja pangan jajanan anak sekolah terkait gizi dan keamanan pangan di Jakarta dan Sukabumi. J Gizi Pangan 5(3): 148-157. DOI: 10.25182/jgp.2010.5.3.148-157.

Wang D, Stewart D, Chang C, Shi Y. 2015. Effect of a school-based nutrition education program on adolescents nutrition-related knowledge, attitudes and behaviour in rural areas of China. Environ Health Preventive Med 20(4): 271-278. DOI: 10.1007/s12 199-015-0456-4.

JMP-06-17-002-Naskah diterima untuk ditelaah pada 27 Maret 2018. Revisi makalah disetujui untuk dipublikasi pada 07 April 2019. Versi Online: http://journal.ipb.ac.id/index.php/jmpi 